\title{
INTENSITAS SERANGAN AKIBAT HAMA PEMAKAN DAUN SETELAH APLIKASI EKSTRAK DAUN BABADOTAN (Ageratum conyzoides L.) PADA TANAMAN SAWI (Brassica juncea L.)
}

\author{
Ayu N.S.A Lumban Gaol ${ }^{1)}$, Henny Lieke Rampe ${ }^{1)}$, Marhaenus Rumondor ${ }^{1)}$ \\ ${ }^{1)}$ Program Studi Biologi, FMIPA Universitas Sam Ratulangi Manado \\ e-mail : ayunovitamarbun@gmail.com; Hennyrampe@unsrat.ac.id ; \\ Marhaenusrumondor66@unsrat.ac.id
}

\begin{abstract}
ABSTRAK
Telah dilakukan penelitian untuk mengevaluasi intensitas serangan akibat hama pemakan daun setelah aplikasi ekstrak daun Babadotan (Ageratum conyzoides L.), pada tanaman sawi (Brassica juncea L.). Penelitian bertempat di lahan percobaan Kelurahan Lansot, Kecamatan Tomohon Selatan, Kota Tomohon, Sulawesi Utara. Penelitian menggunakan metode eksperimen Rancangan Acak Lengkap (RAL) dengan tiga ulangan. Konsentrasi ekstrak daun babadotan dengan empat taraf perlakuan yaitu: $\mathrm{P} 0=$ kontrol, $\mathrm{P} 1=100 \mathrm{~g} / \mathrm{L}, \mathrm{P} 2=200 \mathrm{~g} / \mathrm{L}$ dan $\mathrm{P} 3=300 \mathrm{~g} / \mathrm{L}$. Aplikasi ekstrak daun babadotan dilakukan pada 16 hari setelah tanam (HST), 26 HST dan 36 HST. Parameter yang diamati yaitu luas intensitas serangan. Data yang diperoleh dianalisis dengan ANAVA dan dilanjutkan dengan uji Beda Nyata Terkecil (BNT) pada $\mathrm{p}=0.05$. Hasil penelitian menunjukkan bahwa aplikasi ekstrak daun babadotan menurunkan intensitas serangan hama pemakan daun pada tanaman sawi. Aplikasi ekstrak daun babadotan sebesar $300 \mathrm{gr} / \mathrm{L}$ dapat menekan serangan hama pemakan daun pada tanaman sawi.
\end{abstract}

Kata kunci: Ekstrak daun babadotan (Ageratum conyzoides L.), Tanaman sawi (Brassica juncea L.), Intensitas serangan hama.

\section{INTENSITY OF ATTACK DUE TO LEAF EATER PESTS AFTER APPLICATION OF BABADOTAN LEAF EXTRACT (Ageratum conyzoides 1.). IN MUSTARD PLANTS (Brassica juncea 1.)}

\begin{abstract}
Research has been carried out to evaluate the intensity of attacks due to leaf eater pests after application of babadotan leaf extract (Ageratum conyzoides L.) on mustard plants (Brassica juncea $\mathrm{L}$.). This research took place at the trial area of Lansot village, Tomohon central, Tomohon city, North Sulawesi. The study used the experimental method Completely Random Design with 3 replications. The concentration of babadotan leaf extract with four treatment levels, namely: $\mathrm{P} 0=$ (control), P1= $100 \mathrm{~g} / \mathrm{L}, \mathrm{P} 2=200 \mathrm{~g} / \mathrm{L}$ and $\mathrm{P} 3=300 \mathrm{~g} / \mathrm{L}$. The application of babadotan leaf extract was carried out at 16 days after planting (HST), 26 HST and 36 HST. The parameter observed was the area of intensity. The data obtained were analyzed by ANOVA and LSD comparisons test with $\mathrm{p}$ value 0.05 . The results showed that the application of babadotan leaf extract reduced the intensity of attacks due to leaf eating pests on mustard plants. Application of babadotan leaf exctract of $300 \mathrm{gr} / \mathrm{L}$ can suppress leaf eating pests in mustard plants.
\end{abstract}

Keywords: Babadotan leaf extract (Ageratum conyzoides L.), mustard plant (Brassica juncea L.), Intensity of attack.

Article History:

Received: July 11, 2019

Accepted: July 24, 2019

Published: July 25, 2019

\section{PENDAHULUAN}

Tanaman sawi (Brassica juncea L.) termasuk Famili Brassicaceae merupakan tanaman semusim yang dapat tumbuh pada berbagai jenis tanah di dataran tinggi maupun dataran rendah. Daerah penanaman yang cocok untuk pertumbuhan sawi adalah 5- 
$1200 \mathrm{~m}$ dpl. Tanaman sawi termasuk kelompok tanaman sayuran yang memiliki kandungan gizi tinggi bagi kesehatan tubuh seperti serat, kalori, protein, lemak, karbohidrat, kalsium, fosfor, zat besi, vitamin A, B1, dan C. Menurut Margiyanto (2008), manfaat sawi sangat baik untuk menghilangkan rasa gatal di tenggorokan pada penderita batuk, penyembuh sakit kepala, bahan pembersih darah, memperbaiki fungsi ginjal, serta memperbaiki dan memperlancar pencernaan. Di Indonesia, tanaman sawi cukup popular dan banyak ditanam sebagai salah satu sumberpenghasilan pada masyarakat (Rukmana,2007).

Dalam budidaya tanaman sawi, salah satu kendala yang menjadi penghambat produksi baik dari segi kualitas maupun kuantitas adalah adanya serangan organisme pengganggu tanaman (OPT). Menurut Kardinan (2000), hama utama yang sering menyerang tanaman sawi adalah ulat gantung (Plutella xytostella) dan ulat krop (Crocidolomia binotalis). Hama memakan epidermis daun yang menyebabkan daun berlubang-lubang dan tertinggal tulang daun (Sriniastuti, 2005).

Saat ini untuk penanggulangan hama, biasanya petani menggunakan pestisida kimia. Penggunaan pestisida kimia memberikan dampak negatif bagi kehidupan baik tanaman, hewan, maupun manusia. Hal ini dikarenakan tidak semua pestisida yang digunakan mampu membunuh OPT. Pestisida terbuang ke tanah pada musim kemarau mencapai $30 \%$ dan pada musim hujan dapat mencapai $80 \%$, dan selanjutnya akan terbuang ke dalam perairan. Bahan beracun tersebut akan mempengaruhi biota, baik yang ada di dalam tanah, air, maupun bagian permukaan atas tanaman termasuk mikroba epifit (Kardinan, 2000).

Salah satu solusi untuk menekan penggunaan pestisida kimia adalah menggunakan pestisida nabati. Pestisida nabati adalah pestisida yang berasal dari tanaman atau tumbuhan. Penggunaan pestisida nabati dinilai sangat ekonomis karena bahan yang digunakan dalam pembuatan pestisida nabati, mudah diperoleh dan biaya yang dibutuhkan relatif murah. Nirwana (2012) mengemukakan pestisida nabati dapat berfungsi sebagai senyawa pembunuh, penolak, pengikat, dan penghambat pertumbuhan hama. Akhir-akhir ini perhatian terhadap pestisida nabati semakin meningkat dengan pemanfaatan senyawa-senyawa bioaktif yang berasal dari tanaman. Pestisida nabati mengandung senyawa yang mudah terdegradasi di alam. Saat ini telah diketahui sekitar 2.400 jenis tanaman yang berpotensi sebagai pestisida nabati, salah satunya adalah tumbuhan babadotan (Kardinan, 2000).

Tujuan penelitian ini untuk mengevaluasi intensitas serangan akibat hama pemakan daun setelah aplikasi ekstrak daun babadotan (Ageratum conyzoides) pada tanaman sawi (Brassica juncea)

\section{BAHAN DAN METODE}

\section{Tempat dan Waktu Penelitian}

Penelitian ini dilaksanakan pada bulan Desember 2018 - Februari 2019, bertempat di lahan percobaan Kelurahan Lansot, Kecamatan Tomohon Selatan, Kota Tomohon, Sulawesi Utara.

\section{Metode Penelitian}

Penelitian menggunakan metode eksperimen Rancangan Acak Lengkap (RAL) dengan tiga kali ulangan. Konsentrasi ekstrak daun babadotan dengan empat taraf perlakuan yaitu $\mathrm{p} 0=$ kontrol, $\quad \mathrm{P} 1=100 \mathrm{~g} / \mathrm{L}$, $\mathrm{P} 2=200 \mathrm{~g} / \mathrm{L}$ dan $\mathrm{P} 3=300 \mathrm{~g} / \mathrm{L}$.

\section{Persiapan media tanam dan penyemaian benih sawi}

Untuk pembibitan, benih sawi disiapkan lahan percobaan dengan ukuran panjang 100 $\mathrm{cm}$ dan lebar $50 \mathrm{~cm}$ sebanyak 12 bedeng. Selanjutnya, penentuan perlakuan pada bedengan berdasarkan undian. Benih sawi yang diperoleh dari toko benih selanjutnya direndam dalam air selama satu jam dan selanjutnya disemai di bedengan yang telah dipersiapkan. Pada tiap bedeng, dibuat 8 lubang tanam sedalam $2 \mathrm{~cm}$, selanjutnya benih sawi ditanam dalam lubang dan ditutup dengan tanah secukupnya (Samadi, 2017).

\section{Penjarangan Bibit}

Benih sawi yang sudah berumur 14 Hari Setelah Tanam (HST) (berdaun 2 helai), dilakukan penjarangan yaitu dengan 
menyisakan 1 tanaman dalam setiap lubang tanam.

\section{Pemeliharaan Tanaman Sawi}

Pemeliharan pada tanaman sawi adalah dengan menyiangi gulma yang tumbuh dan menyiram tanaman pada saat musim kemarau, untuk menghindari kekeringan dari tanaman sawi tersebut.

\section{Pembuatan Ekstrak Daun Babadotan}

Pembuatan ekstrak daun babadotan dengan cara daun babadotan dicuci bersih dengan air mengalir, lalu dikeringanginkan. Untuk Perlakuan 1 (P1), daun sebanyak 100 $\mathrm{g}$ dipotong sekitar $2 \mathrm{~cm}$ kemudian ditambahkan akuades lalu diblender. Setelah bahan tanaman halus kemudian disaring. Ampas selanjutnya dihaluskan kembali dan disaring sampai yang tersisa ialah serat tanaman. Supernatan digenapkan menjadi 1 $\mathrm{L}$ dengan akuades. Untuk P2, caranya sama hanya berat daunnya yang berbeda yaitu P2 sebanyak 200 g, dan P3 sebanyak 300 g daun babadotan.

\section{Aplikasi Ekstrak}

Aplikasi ekstrak dilakukan pada saat daun sawi berumur 16 HST, 26 HST dan 36 HST, yaitu dengan menyemprotkan ekstrak ke seluruh bagian tumbuhan sesuai perlakuan. Penyemprotan dalam satu bedeng memerlukan waktu 1-2 menit.

\section{Pengamatan}

Parameter yang diamati ialah menghitung luas serangan oleh hama pemakan daun yaitu dengan menggunakan rumus yang dikemukakan oleh Natawigena (1989) dalam Wali dan Soamole (2015) yang telah dimodifikasi. Skala intensitas kerusakan daun sawi ditentukan dengan menggunakan metode panjang kali lebar menggunakan kertas millimeterblok.

$\mathrm{P}=\frac{a}{b} \times 100 \%$

Dimana:

$\mathrm{P}=$ Luas serangan

$\mathrm{a}=$ Luas daun yang diserang

$\mathrm{b}=$ Luas daun

Pengukuran daun yang pertama sekali dilakukan yaitu dengan mengukur keseluruhan daun dengan menggunakan kertas millimeter blok dengan metode panjang kali lebar. Lalu luas serangan diukur dengan cara yang sama seperti mengukur luas daun, kemudian dijumlahkan. Pengamatan setelah aplikasi ekstrak daun babadotan dilakukan 3 kali yaitu pada saat tanaman sawi berumur 14 HST, 28 HST dan 42 HST.

Tabel 1. Penentuan Nilai Skala Tiap Kategori Serangan

\begin{tabular}{ccc}
\hline $\begin{array}{c}\text { Nilai } \\
\text { Skala }\end{array}$ & Persentase & $\begin{array}{c}\text { Kategori } \\
\text { Serangan }\end{array}$ \\
\hline 0 & - & Normal \\
1 & $0-25$ & Ringan \\
2 & $25-50$ & Sedang \\
3 & $50-75$ & Berat \\
4 & 75 & Sedang \\
& & Berat \\
\hline
\end{tabular}

\section{Analisis Data}

Data yang diperoleh dari hasil penelitian ini dianalisis dengan ANAVA, dan dilanjutkan dengan uji BNT yaitu $\mathrm{p}=0,05$ (Hanafiah, 2004).

\section{HASIL DAN PEMBAHASAN}

Data rerata intensitas serangan dari setiap daun untuk setiap tanaman disajikan pada. Tabel 2 .

Tabel 2. Rerata Intensitas Serangan Hama Pemakan Daun pada Tanaman Sawi

\begin{tabular}{lcccc}
\hline Perlakuan & \multicolumn{3}{l}{ Ulangan } & \multicolumn{3}{c}{ Rerata \pm SD } \\
\cline { 2 - 5 } & 1 & 2 & 3 & \\
\hline $\begin{array}{l}\text { Kontrol } \\
(\text { P0) }\end{array}$ & 4,76 & 4,66 & 7,46 & $5,63 \pm 1,59$ \\
$\begin{array}{l}\text { P1 (100 g } \\
\text { ekstrak) }\end{array}$ & 1,65 & 1,36 & 0,88 & $1,30 \pm 0,39$ \\
$\begin{array}{l}\text { P2 (200 g } \\
\text { ekstrak) }\end{array}$ & 0,89 & 2,28 & 0,67 & $1,28 \pm 0,87$ \\
$\begin{array}{l}\text { P3 (300 g } \\
\text { ekstrak) }\end{array}$ & 0,23 & 1,53 & 0,86 & $0,87 \pm 0,65$ \\
\hline Ket: SD & & & & \\
\hline
\end{tabular}

Ket: $\mathrm{SD}=$ Standar Deviasi

Berdasarkan Tabel 2 diperoleh nilai rerata intensitas serangan yang paling tinggi pada perlakuan P0 (kontrol) yaitu 5,63 $\pm 1,59$, dan yang paling rendah pada perlakuan P3 yaitu $0,87 \pm 0,65$.

Data hasil analisis varians intensitas serangan hama pada tanaman sawi setelah aplikasi daun babadotan diperoleh hasil seperti ditunjukkan pada Tabel 3. 
Tabel 3. Hasil Analisis Varians Intensitas Serangan Hama Pemakan Daun pada Tanaman Sawi.

\begin{tabular}{llllll}
\hline SK & DB & JK & KT & F & F \\
& & & & Hitung & 0,05 \\
\hline Perlakuan & 3 & 45,44 & 15,14 & $15,70^{*}$ & 4,07 \\
Galat & 8 & 7,71 & 0,96 & & \\
Total & 11 & 53,16 & & & \\
\hline
\end{tabular}

Ket: *berbeda nyata

Berdasarkan data Tabel 3 diperoleh nilai $\mathrm{F}$ Hitung yaitu $15,70>$ nilai Ftabel 0,05 yaitu 4,07, menunjukkan bahwa pemberian ekstrak daun babadotan berpengaruh nyata dalam menurunkan intensitas serangan pada tanaman sawi.

Hasil Uji BNT tingkat serangan hama pemakan daun setelah perlakuan ekstrak daun babadotan P0, P1, P2 dan P3 dapat dilihat pada Tabel 4. Berdasarkan data menunjukkan antara perlakuan P0-P1, P0P2, P0-P3, berbeda nyata pada tarif uji 0,05, selanjutnya antara perlakuan P1-P2, P1-P3 dan P2-P3 menunjukkan hasil yang tidak berbeda nyata pada taraf uji 0,05 .

Tabel 4. Hasil Uji Beda Nyata Terkecil (BNT) 0,05 untuk Intensitas Serangan Hama Pemakan Daun Pada Tanaman Sawi.

\begin{tabular}{cl}
\hline Perlakuan & Rerata \pm SD \\
\hline P0 & $5,63 \pm 1,59^{\mathrm{a}}$ \\
P1 & $1,30 \pm 0,39^{\mathrm{b}}$ \\
P2 & $1,30 \pm 0,87^{\mathrm{b}}$ \\
P3 & $0,87 \pm 0,65^{\mathrm{b}}$
\end{tabular}

Ket: Angka yang diikuti huruf yang sama menunjukkan tidak berbeda nyata berdasarkan uji BNT 0,05

$\mathrm{SD}=$ standar deviasi

Babadotan termasuk salah satu gulma potensial dan dapat hidup di ladang, tepi jalan, dan tepi air. Bahan aktif yang terkandung dalam daun babadotan berupa alkaloid, saponin, flavanoid, polifenol, sulfur dan tanin yang menghambat pertumbuhan tanaman. Bagian daun babandotan memiliki sifat insektisidal dan alelopati (Grainge dan Ahmed, 1988). Babadotan merupakan gulma yang dapat berpotensi sebagai bioherbisida karena mempunyai senyawa alelopati (Sukamto, 2007).

Rendahnya intensitas serangan hama yang menyerang tanaman sawi dapat disebabkan karena babadotan ini mengandung metabolit sekunder seperti flavonoid, alkaloid, terpena, kromon, benzofuran, kumarin, minyak atsiri, sterol, dan tanin senyawa fenol pada daun, dapat menghambat pertumbuhan gulma.

Pengamatan saat tanaman sawi berumur 14 tanaman sawi diserang oleh ulat grayak (Spodoptera litura), ulat tritip (Plutella xylostella) dan ulat tanah hitam Agrotis ipsilon (Gambar 1, 2 dan 3).
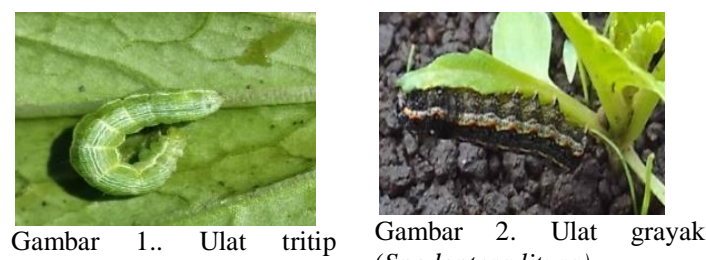

(Plutella xylostella)

(Spodoptera litura)

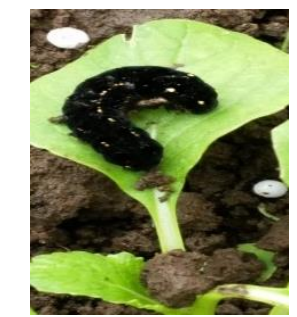

Gambar 3. Ulat

Agrotis ipsilon

Pada pengamatan setelah aplikasi penyemprotan pertama ekstrak daun babadotan, intensitas serangan berkurang. Selanjutnya, pengamatan setelah aplikasi ekstrak penyemprotan kedua dan ketiga intensitas serangan sangat kecil. Hal ini membuktikan bahwa ekstrak dari daun babadotan mampu membunuh hama dalam jangka waktu yang cepat. Pestisida nabati dapat membunuh atau mengganggu serangga hama melalui cara kerja yang unik, yaitu dapat melalui perpaduan berbagai mekanisme atau secara tunggal (Anonim 2010).

Semua perlakuan yang diberikan efektif dalam pengendalian ulat tritip, ulat tanah maupun ulat grayak. Hal ini sesuai dengan pernyataan Kardinan (2011) yang mengatakan bahwa keefektifan suatu insektisida dapat dinilai berdasarkan banyaknya populasi hama setelah pemberian perlakuan, ataupun berdasarkan kemampuan konsentrasi pestisida untuk membasmi hama uji lebih dari 50\% dalam kurun waktu 24 jam setelah aplikasi. Menurut Schoonhoven 
(1982) alkaloid dan terpenoid sangat berpotensi sebagai penghambat makan pada sejumlah serangga. Biasanya pada larva Lepidoptera ditemukan suatu reseptor khusus berupa sel sensilla yang terdapat pada maksila. Sel tersebut dapat merespon berbagai alkaloid yang pada konsentrasi tertentu beraksi sebagai penghambat makan.

Berdasarkan hasil uji beda nyata (BNT) pada Tabel 2, intensitas serangan hama pada tanaman sawi antara perlakuan P1-P2, P1-P3, dan P3-P2, memiliki nilai lebih besar dari BNT 0,05 yaitu 1,84 yang berarti berbeda nyata pada taraf uji 0,05 . Selanjutnya antara perlakuan P0-P1, P0-P2, dan P0-P3, memiliki nilai yang lebih kecil dari nilai BNT 0,05 yaitu 1,84 yang berarti tidak berbeda nyata pada taraf uji 0,05 . Hal ini menunjukkan bahwa reaksi serangga terhadap senyawa alelokimia tertentu tergantung pada dosisnya. Penghambatan total oleh suatu senyawa anti makan terjadi pada kisaran dosis efektif tertentu, dimana perlakuan ekstrak daun babadotan $100 \mathrm{~g}$ ekstrak, 200 g ekstrak, 300 g ekstrak, berbeda dengan perlakuan ekstrak $0 \mathrm{~g}$ ekstrak (kontrol). Hal ini membuktikan bahwa semakin tinggi konsentrasi ekstrak daun babadotan maka tingkat kerusakan sawi semakin rendah.

Menurut Lumowa (2011), flavonoid dapat dimanfaatkan sebagai bahan aktif dalam pembuatan insektisida nabati. Bahan aktif pada insektisida botani tersebut mampu menyebabkan gangguan aktivitas makan dengan mengurangi nafsu makan, memblokir kemampuan makan serangga sehingga hama menolak makan (Astriani, 2010). Selanjutnya , menurut Suryani (1991) dalam Sanyoto (2003), alkaloid merupakan senyawa pahit dan beracun dapat menyebabkan rasa pusing dan tidak mau makan dan akhirnya mati. Lebih lanjut, Samsudin (2008) menyatakan bahwa kandungan aktif tanaman babadotan adalah saponin, flavonoid, dan polifenol mampu mencegah hama mendekati tanaman (penolak) dan mampu menghambat pertumbuhan larva.

Saponin yang termasuk senyawa glikosida memiliki sifat khas apabila diaduk menghasilkan busa. Saponin dapat merusak saraf hama dan mengakibatkan nafsu makan berkurang dan akhirnya hama mati (Marfuah, 2005 dalam Darmayanti, 2006). Tanin dapat bereaksi dengan protein dan menimbulkan masalah pada aktivitas enzim sehingga semakin tinggi tanin dapat membantu mengusir hama yang menyerang tanaman sawi. Minyak atsiri merupakan bahan terpenoid yang mudah menguap dan menghasilkan bau sesuai tanaman aslinya. Senyawa ini mampu menghambat tumbuhan lain dan membunuh hama dengan toksik yang tinggi.

Tabel 4. Nilai Skala Tiap Kategori Serangan

\begin{tabular}{cl}
\hline Perlakuan & Persentase \\
\hline P0 & $5,63 \%$ \\
P1 & $1,30 \%$ \\
P2 & $1,28 \%$ \\
P3 & $0,87 \%$ \\
\hline
\end{tabular}

Kategori serangan hama menunjukkan bahwa intensitas serangan yang terjadi pada perlakuan P0, P1, P2 maupun P3, menunjukkan serangan kategori ringan (Tabel 4).

\section{KESIMPULAN DAN SARAN}

\section{Kesimpulan}

Ekstrak daun babadotan mampu menurunkan intensitas serangan akibat hama pemakan daun setelah aplikasi ekstrak daun babadotan (Ageratum conyzoides L.) pada tanaman sawi (Brassica juncea L.). Konsentrasi ekstrak daun babadotan yang dapat menekan serangga hama pemakan daun yaitu yang tertinggi pada perlakuan P3 (300 g ekstrak).

\section{Saran}

Perlu dilakukan penelitian lebih lanjut untuk menguji potensi tumbuhan babadotan (Ageratum conyzoides L.), sebagai pestisida nabati dengan membuat ekstrak dari akar, batang dan bunga untuk melengkapi informasi penelitian ini yang memanfaatkan ekstrak daun babadotan.

\section{DAFTAR PUSTAKA}

Anonim 2010. Tanaman untuk Pestisida Nabati SmallCrab.com informasi kesehatan dan lainlain.(http://www.smallcrab.com [23 Juli 2013]. 
Grainge, M.S. dan Ahmed. 1988. Handbook of Plants with Pest-Control Properties. John Wiley \& Sons. Inc. Canada.

Hanafiah, A.K. 2004. Rancangan Percobaan, Edisi Ketiga. Raja Grafindo Persada, Jakarta.

Kardinan, A. 2000. Pestisida Nabati, Ramuan dan Aplikasinya. Penebar Swadaya. Jakarta.

Lumowa, S. V. V. 2011. Efektivitas Ekstrak Babadotan (Ageratum conyzoides L.) terhadap Tingkat Kematian Larva Spodoptera litura F. Eugenia, 17(3).

Nirwana, 2012. Kemampuan pestisida nabati (mimba, gadung, laos dan serai), terhadap hama tanaman kubis (brassica oleracea 1). Agritrop Jurnal ilmuilmu pertanian.1(4): 207-211.

Rukmana, R. 2007. Bertanam Petsai dan Sawi. Kanisius. Yogjakarta.

Samadi, B. 2017. Teknik Budidaya Sawi dan Pak Choy. Jakarta.
Samsudin, H. 2008. Pengendalian Hama Dengan Insektisida Botani. Bumi Aksara. Jakarta.

Schoonhoven, LM. 1982. Biological a spects of antifeedant. Entomologi Experimental. \& Applied. 31: 57-69.

Sriniastuti, 2005. Efektifitas Penggunaan Bacillus thuringiensis terhadap Serangan Ulat Daun (Plutella xylostella) pada Tanaman Sawi (Brassica juncea L.) di Sungai Selamat, [Skripsi], Fakultas Pertanian Universitas Tanjungpura, Pontianak.

Sukamto. 2007. Babadotan (Ageratum conyzoides) Tanaman Multi Fungsi. Warta Puslitbangbun 13 (3).

Wali, M., dan S. Soamole. 2015. Studi Tingkat Kerusakan Akibat Hama Daun pada Tanaman Meranti Merah (Shorea leprosula) di Areal Persemaian PT. Gema Hutani Lestari Kec. Fene Leisela. Jurnal Ilmiah dan Agribisnis Perikanan. 8(2): 36-45. 